\title{
Comperative Investigation of Structure of Male Genital System of Ductus Deferens Ligation in Rats
}

\author{
Duktus Deferens Ligasyonu Yapilmiş Ratlarda Erkek Genital Sisteminin Karşılaştırmalı olarak İncelenmesi
}

\author{
Hazal Demir Yarar ${ }^{1}$, Suna Ömeroğlu², ilker Şen ${ }^{3}$, Neslihan Coşkun Akçay ${ }^{4}$, Saadet Özen Akarca Dizakar ${ }^{2}$, Fatih Bıçaklıoğlu \\ İsmail Türkoğlu²
}

${ }^{1}$ Çukurova University Faculty of Medicine, Department of Histology and Embryology, Adana, Turkey

${ }^{2}$ Gazi University Faculty of Medicine, Department of Histology and Embryology, Ankara, Turkey

${ }^{3}$ Gazi University Faculty of Medicine, Department of Urology, Ankara, Turkey

${ }^{4}$ Hacettepe University Faculty of Medicine, Department of Obstetrics and Gynecology, Ankara, Turkey

\section{ABSTRACT}

Objective: We investigated structural and morphological changes in prepubertal and pubertal rat testis and ductus deferens after unilateral vasectomy. Vasectomy is reliable and popular male contraception method, applied widely in the world.

Methods: Six pre-pubertal and 6 pubertal male Wistar albino rats were divided into four groups. Unilateral ductus deferens ligation was performed on right ductus deferens of each rat. Right testis and ductus deferens tissues were evaluated as ligation group while left tissues were control groups. Two months after operation, the vas deferens and testes removed to obtain paraffin block sections and morphometric studies carried out with light microscopy. Hematoxylin-eosin staining and vascular endothelial growth factor (VEGF) immunohistochemically staining were applied.

Results: Structural and morphological changes and decrease in spermatogenesis process have been observed at testis and ductus deferens tissues of all vasectomized rat. The seminiferous epithelium and the seminiferous tubule diameter were thickened. Degenerative changes have been observed at the epithelial structure of Ductus deferens and among muscle fibers forming the muscle of the Ductus deferens. Moreover, in prepubertal and pubertal vasectomized rat VEGF immunoreactivity was not observed in seminiferous tubule.

Conclusion: The unilateral ligation operation can cause damage at ductus deferens and testis tissue in the pre-pubertal and pubertal period.

Key Words: Ductus deferens ligation, ductus deferens, testis, vascular endothelial growth factor, puberty, prepuberty.

Received: 06.29.2017
Accepted: 09.22.2017

\section{ÖZET}

Amaç: Tek taraflı vazektomi sonrası prepubertal ve pubertal sıçan testislerindeki ve duktus deferenslerindeki yapısal ve morfolojik değişiklikler araştırıldı. Vazektomi dünyada yaygın olarak uygulanan güvenilir ve popüler bir erkek doğum kontrol yöntemidir.

Yöntem: Altı puberte öncesi ve 6 pubertal dönemdeki Wistar albino cinsi erkek sıçan 4 gruba ayrıldı. Her sıçanın sağ duktus deferensine tek taraflı duktus deferens ligasyonu işlemi uygulandı. Sağ testis ve duktus deferens dokuları ligasyon grubu, sol dokular ise kontrol grupları olarak değerlendirildi. Operasyondan iki ay sonra, vas deferens ve testis dokuları parafin blok kesitleri elde etmek için çıkarıldı ve morfometrik çalışmalar ışık mikroskobu kullanılarak gerçekleştirildi. Hematoksilen-eozin boyama ve Vasküler endotelyal büyüme faktörü (VEGF) kullanılarak immünhistokimyasal boyama yapıldı.

Bulgular: Tüm vazektomi uygulanmış sıçanların testis ve duktus deferens dokularında yapısal ve morfolojik değişiklikler olduğu ve spermatogenezis sürecinde azalmanın olduğu gözlemlenmiştir. Seminifer tübül epitel çapı ve seminifer tübül çapı artmıştır.

Duktus deferens'in epitel yapısında ve Duktus deferens kasını oluşturan kas lifleri arasında dejeneratif değişiklikler olduğu gözlemlenmiştir. Ayrıca, prepubertal ve pubertal vazektomize sıçanlarda seminifer tübüllerde VEGF immünreaktivitesi gözlenmemiştir

Sonuç: Puberte öncesi ve pubertal dönemde tek taraflı ligasyon operasyonu, duktus deferens ve testis dokusunda hasarına neden olabilir.

Anahtar Sözcükler: Duktus deferens ligasyonu, duktus deferens, testis, vasküler endoteliyal büyüme faktörü, puberte, puberte öncesi.

Geliş Tarihi: 29.06.2017

Kabul Tarihi: 22.09.2017

Address for Correspondence / Yazışma Adresi: İsmail Türkoğlu, Phd Candidate, Gazi University Faculty of Medicine, Histology and Embryology Department Building the Academic Deanship, 4th floor Besevler, Ankara, Turkey E-mail: ismailt.turkoglu@gmail.com

CTelif Hakkı 2018 Gazi Üniversitesi Tıp Fakültesi - Makale metnine http://medicaljournal.gazi.edu.tr/ web adresinden ulaşılabilir.

CC Copyright 2018 by Gazi University Medical Faculty - Available on-line at web site http://medicaljournal.gazi.edu.tr/

doi:http://dx.doi.org/10.12996/gmj.2018.26 


\section{INTRODUCTION}

Vasectomy is an effective and a safe method of contraception used by men commonly all over the world $(1,2)$. An approximate 33 million of married women worldwide rely on their partner's vasectomy for contraception (2).

There are many controversial results about the male reproduction damage vasectomy in the literature. Many studies have been done to examine the damage and changes after vasectomy. In animal experimental studies, there was an increase in testicular degeneration in proportion to time after vasectomy operation. Compared with the findings of experimental studies on animals, no significant changes of degeneration were found in human studies. However, it was remarkable that fertility was low (3-6).

According to some researchers, vasectomy does not affect sperm production. However, since the spermatozoa produced cannot move along the duct due to occlusion, bilateral binding to the ductus deferens, sperm granulomas located along the ductus deferens and ductus epididymis are observed. In some studies on rabbits, sperm granulomas were not found. Due to the easily tearable structure of the ductus epididymis in human experiments, it is thought that the rise of pressure hinders the reflection of seminiferous tubules $(5,7-10)$.

In experimental studies performed, it was observed that the histological structure of testicular tissue was damaged from the first months after vasectomy and increased in proportion to time. This damage and change in Sertoli cells was less than in spermatogenic cell lines. In seminiferous tubules, vacuoles were observed in the first months, together with spermatogenic cell losses (11).

Vascular endothelial growth factor (VEGF) is an angiogenic peptide and a growth factor specific for endothelial cells. It is a principal regulator of vasculogenesis and angiogenesis (12-14). Vascular endothelial growth factor (VEGF) is known to influence testis function $(15,16)$. Leydig cells and other testicular cells secrete vascular endothelial cell growth factor (VEGF), whereas the receptors, VEGF-R1 and VEGF-R2 are expressed on testicular blood vessels $(15,17,18)$

The main goal of our study was the examination of structural and morphological changes in testis and ductus deferens and demonstrate alterations of VEGF immunoreactivity in rat testes after vasectomy by means of light microscopy.

\section{MATERIALS and METHODS}

Animals and experimental design

Animals were obtained from the Animal Breeding and Experimental Research Laboratory of Gazi University. The experimental protocol was approved by the Ethical Committee of Gazi University. In this study, 6 prepubertal ( 10 days old) and 6 pubertal ( 60 days old) male Wistar Albino rats were used. The animals were kept at $25 \pm 2^{\circ} \mathrm{C}$ temperature and $32 \pm 7 \%$ humidity in a $12 \mathrm{~h}$ light/dark cycle. Rats were provided pelleted food and water ad libitum.

Unilateral ductus deferens ligation was performed on right ductus deferens of each rats. Right testis and ductus deferens tissues were evaluated as ligation group and left vas deferens was not ligated, left testis and ductus deferens were evaluated control group. The animals divided into 4 groups. Group 1: Pre-pubertal control group $(n=6)$ : At the beginning of the experiment vas deferens was not unilateral ligation; Group 2: Pre-pubertal vas deferens ligation group $(n=6)$ at the beginning of the experiment unilateral vas deferens ligation performed. Group 3: Pubertal control group: $(n=6)$ at the beginning of the experiment vas deferens was not unilateral ligation Group 4: Pubertal ligation group: $(n=6)$. At the beginning of the experiment unilateral vas deferens ligation performed. After 2 months all the animals was sacrificed and the vas deferens and testis removed.

\section{Vas Deferens Ligation}

The rats were anesthetized with an intraperitoneal injection of $0.15 \mathrm{ml}$ (2\%) Rompun ${ }^{\mathrm{TM}}$ (xylazine) and $0.30 \mathrm{ml}$ (10\%) Ketasol (Ketamin). 2-3 cm midline suprapubic incision was made. The bladder and intestines were retracted and right vas deferens was identified then opened tunica vaginalis. About $10 \mathrm{~mm}$ tissue was resected from vas deferens and then the distal vas deferens was ligated with $5 / 0$ silk sutures. Then, testis and other attachments were sent into scrotum. The suprapubic incision was closed with a 2 -layer $3 / 0$ vicrly.
Before and after the surgical procedure, the suture area was cleaned with antiseptic solution. After two months the animals in all the groups were sacrificed and testis and vas deferens tissues removed.

\section{Histological and morphometric investigation}

The removed testes and vas deferens were fixed in $10 \%$ formaldehyde, then the tissues were processed the routine histological procedure and embedded in paraffin block. Tissue sections of 4-5 $\mu \mathrm{m}$ thickness were taken with a microtome. The sections stained with hematoxylin-eosin (HE). The slides were evaluated under light microscope (Leica DM4000 B, Germany). The thickness of seminiferous tubules epithelium and diameter of seminiferous tubules were measured under the light microscope with computer supported imaging system.

\section{Immunohistochemical Examination}

For immunohistochemical analyses 4-5 $\mu$ m-thick sections were taken with microtome (Leica MR 2145). VEGF (Ab-1) (Cat: RB- 222-P1, Lot:222p810C, Neomarkers, Fremont, CA) rabbit polyclonal antibody was used for the immunohistochemical studies to investigate vascularization in testes. After deparaffinization, rehydration and leaving in distilled water for $5 \mathrm{~min}$, the samples were incubated in 1 M EDTA buffer $(\mathrm{pH}: 6.0)((\mathrm{pH}: 6.0)$ (Cat: AP- $9004-$ 500, Lot: AX201103, Lab Vision, Fremont, USA). Then, the sections were incubated in $3 \% \mathrm{H}_{2} \mathrm{O}_{2}$ (Cat: TA-125- hp, Lot: HP18180, Lab Vision, Fremont, USA) for 15 min to inhibit endogenous peroxidase activity and after $\mathrm{H}_{2} \mathrm{O}_{2}$ treated the testes sections were washed in phosphate buffer solution (PBS). UltraV block (Cat: TA-125-UB, Lot: AUB110414, Lab Vision, Fremont, USA) was applied to prevent non-specific binding and following the blocking, the sections were incubated with primary antibody VEGF (1:100 dilution) for 60 min. Then, the sections were washed in PBS and incubated with biotinylated secondary antibody (Cat: TR-125-BN, Lot: RBN100924, Lab Vision, Fremont, USA) for $20 \mathrm{~min}$. After washing with PBS, the sections were conjugated with streptavidin peroxidase complex (Cat: TS-125- HR, Lot: SHR110303, Lab Vision, Fremont, USA) for 20 min. Finally, sections were incubated with AEC (3- amino9-ethylcarbazole) (Cat: TA-125-SA, Lot: ASA110429, Lab Vision, Fremont, USA Mayer's hematoxylin (Cat: TA-125-MH, Lot: AMH70809, Lab Vision, Fremont, USA) was used for background staining. The sections with Ultramount medium (Cat: TA-125-UG, Lot: VM13518, Lab Vision, Fremont, USA) were ready for microscopic examination. Immunohistochemical analyses of VEGF were studied in testes paraffin sections via imaging system (Leica Q Vin 3).

\section{Statistical Analysis}

Statistical analyses of data were performed with the Statistical Package for Social Sciences (SPSS) v.11 software for Windows. Non-parametric data was analyzed Mann-Whitney $U$ test. P-values < 0.05 were considered statistically significant.

\section{RESULTS}

\section{HE Staining}

According to our histological results we observed that the ovale or irregular seminiferous tubules and immature interstitial area in testes tissue of pre-pubertal control group (Figure 1.A, 1.B). Leydig cells and blood vessels were clearly distinguished in interstitium. Seminiferous tubules including that more immature differentiation stage spermatogenic series such as spermatogonia, spermatocytes. Sertoli cells have been observed along the basement membrane.

When we evaluated the testes of pre-pubertal vas deferens ligation group, degeneration and irregular boundaries of seminiferous tubules were observed. Irregularities in cells of the spermatogenic series were seen. Sertoli cells were not clearly distinguished in the basal compartment. Degeneration and necrosis of interstititum and fewer Leydig cells have been observed (Figure 1.C, 1.D).

The normal histological structure of the testes was observed in the cells of spermatogonial series, the Sertoli and Leydig cells in the pubertal control group. The interstitium is more regular appearance compared with the control pre-pubertal control group. (Figure 1.E, 1.F)

In the testes section of pubertal vas deferens ligation group, degeneration in seminiferous tubules and significant loss of the developing spermatogenic cell series were observed. The composition of interstitium was not clearly distinguished (Figure 1.G, 1.H). 


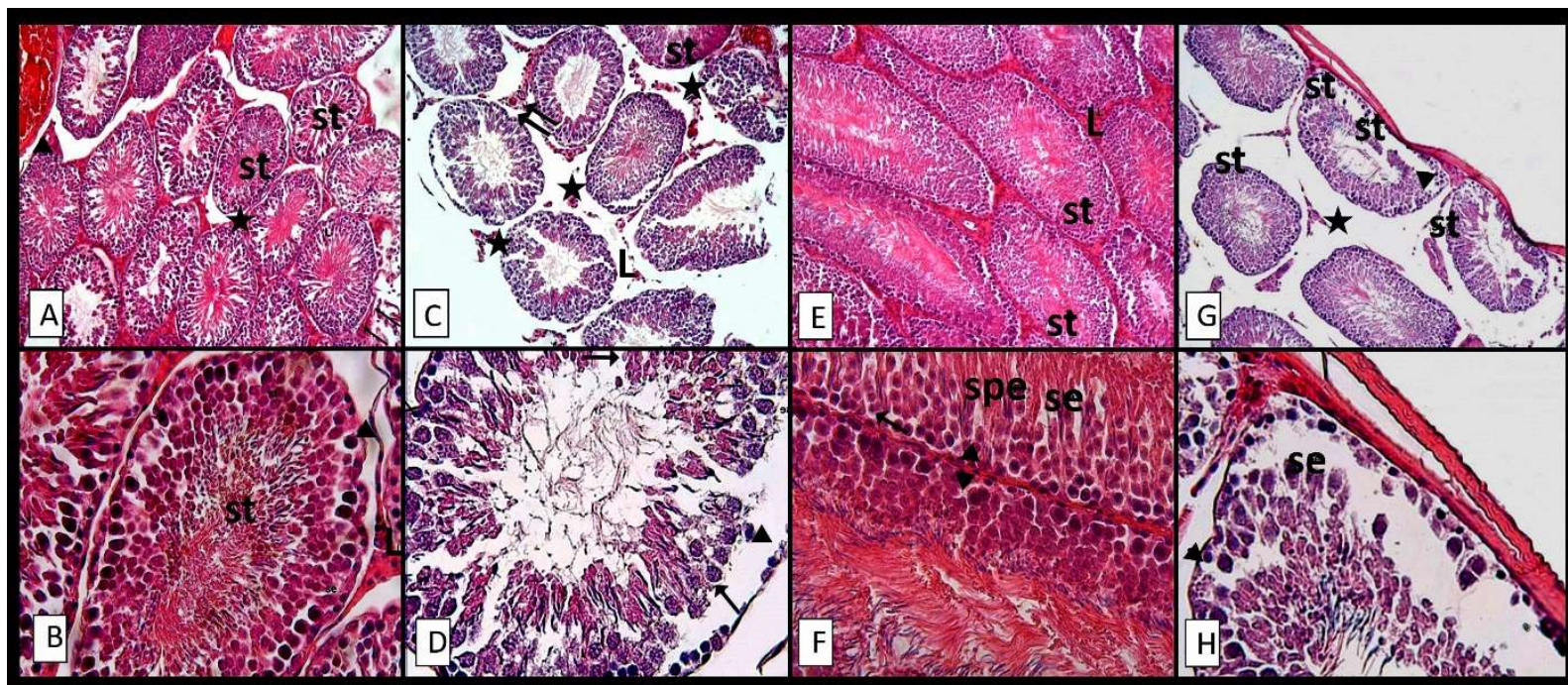

Figure 1: Histologic examination of testis in all groups.

(A-B) Pre-pubertal control group: Normal histologic structure for prepubertal period apperance in testis, (C-D) Pre-Pubertal ligation group: Degeneration and irregular boundaries of seminiferous tubules and cells were observed, (E-F) Pubertal control group: Testicular section showing normal histological apperarance, (G-H) Pubertal ligation group: Testicular section shows severe degeneration and loss of the developing spermatogenic cell series.

Seminiferous tubules (st), spermatogonia $(\mathbf{A})$, interstisium $(\star)$, Leydig Cells $(L)$, Sertoli cell (se), vascular structures $(\kappa \pi)$, cells of spermatogenic series $(\kappa)$, spermatid (spe). (A, C, E, G, H\&E, Magnificatin x10; B, D, F, H, H\&E, Magnification x40)

The histological analysis of vas deferens in pre-pubertal control group clearly revealed that pseudostratified columnar epithelium and lamina propria appeared normal. It was noted that the muscular layer consisted of muscle fibers that were still in one direction compared to the pubertal control group. Tunica adventitia had numerous nerves and blood vessels, but that the connective tissue fibers and cells were not clearly observed (Figure 2.A).

Microscopic examination of vas deferens in the vasectomized prepubertal rats was showed that luminal epithelium and underlying tissues were separated from each other and tissue integrity impaired (Figure 2.B). There were degenerative changes between pseudostratified columnar epithelial cells stereo cilia of which was different lengths and muscular layer (Figure 2.B).
Pseudostratified columnar epithelial cells stereo cilia of which was different lengths. The vas deferens of pubertal rat group showed that normal histologic structure. Luminal epithelium, lamina propria, muscular layer and tunica adventitia were normal morphology (Figure 2.C). In the vasectomized pubertal rats, irregular morphology for stereosilium, muscle fiber of muscular layer and thinned lamina propria were seen comparison to the control sections of pubertal rat. Connective tissue content was altered and a decrease in the structural integrity was observed in tunica adventitia layer compared to control group (Figure 2.D)

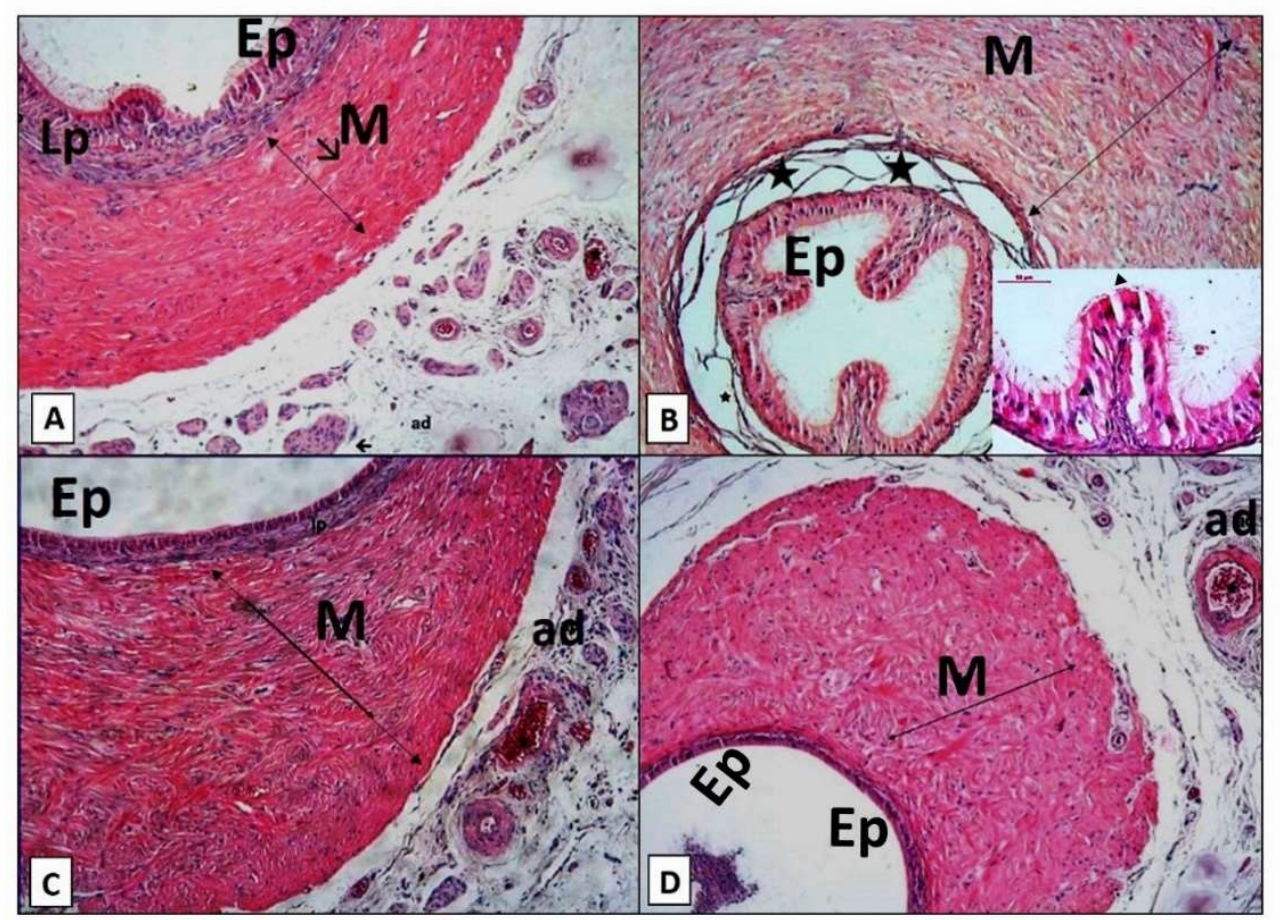

Figure 2: Histologic examination of vas deferens in all groups. (A) Vas deferens section of pre-pubertal control group: pseudostratified columnar epithelium and lamina propria appeared normal. (B) Pre-pubertal ligati group: degenerative changes in pseudostratified columnar epithelial and muscular layer. (C) Pubertal control group showed that normal histologic structure. (D) Pubertal ligation group: irregular morphology for stereosilium, muscle fiber of muscular layer and thinned lamina propria. pseudostratified columnar epithelium (Ep), Lamina propria (Lp), muscular layer (M-double-sided arrows), blood vessels ( $\star$ ), muscle cells ( $\mathbf{\Xi}$ ), degenerative changes (A) and tunica adventitia (ad) (A-D; H\&E, Magnification x10) 


\section{VEGF Staining}

In the pre-pubertal and pubertal control group, VEGF immunoreactivity was observed for the spermatogenic cells in the seminiferous tubules and in the endothelial cells of the blood vessels (Figure 3.A). positive staining in the spermatogenic series and endothelium of blood vesse in vasectomized pre-pubertal and pubertal rats (Figure 3.B). VEGF immunostaining was observed strongly for spermatogenic series and Sertoli cells in compared to ductus deferens, pubertal group (Figure 3.C). VEGF immunoreactivity was not observed for the sections of testis in the ligation group of pubertal rat (Figure 3.D).

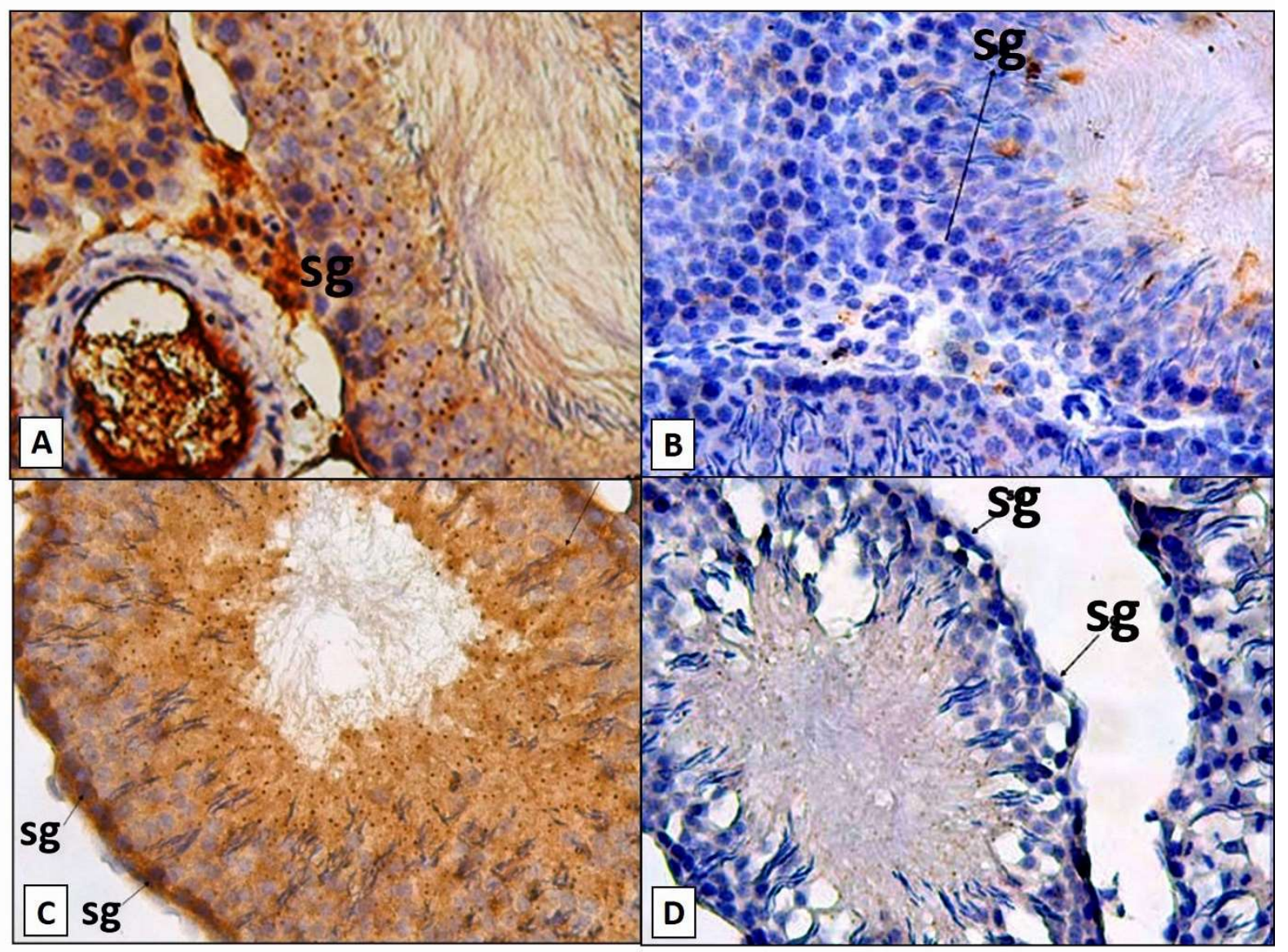

Figure 3: VEGF immunostaining in testicular tissue: A) Pre-pubertal control group, B) Pre-Pubertal ligation group, C) Pubertal control group, D) Pubertal ligation group (A-D, Magnification, $x 40)$

\section{Statistical Analysis}

Evaluation of Diameter and thickness of the seminiferous tubules

Thickness of the seminiferous tubules epithelium and diameter of the seminiferous tubules were measured in 10 randomly selected areas in 36 sections $(n=36)$ in six cross-sections from each experimental group. Mean \pm Standard deviation, median and minimum /maximum values were displayed in table 1. The diameter and epithelium thickness of seminiferous tubule of rats from pubertal control group was significantly higher than pubertal ligation group $(p=0.000)$. We found that the diameter and epithelium thickness of seminiferous tubule of pre-pubertal control group rats, were significantly higher compare to of those of ligation group $(p=0,000)$.

Table 1. Morphometric results obtained from the testis

\begin{tabular}{ccccc}
\hline Parameter analysed & $\begin{array}{c}\text { Group } \mathbf{1} \\
(\mathbf{n}=6)\end{array}$ & $\begin{array}{c}\text { Group 2 } \\
(\mathbf{n}=6)\end{array}$ & $\begin{array}{c}\text { Group 3 } \\
(\mathbf{n}=6)\end{array}$ & $\begin{array}{c}\text { Group 4 } \\
(\mathbf{n}=6)\end{array}$ \\
\hline Diameter of the seminiferous tubules $(\boldsymbol{\mu m})$ & $22,11 \pm 2,83$ & $15,05 \pm 4,09$ & $23,20 \pm 3,0$ & $18,88 \pm 3,46$ \\
Mean \pm SD & 22,82 & 14,12 & 23,13 & 19,13 \\
Median & $14,14 / 29,19$ & $8,95 / 22,49$ & $16,34 / 29,18$ & $10,19 / 27,70$ \\
Min/ Max & & & & \\
Thickness of the seminiferous tubules & $(\boldsymbol{\mu m})$ & & & \\
Mean \pm SD & $57,50 \pm 12,16$ & $34,95 \pm 6,52$ & $77,65 \pm 14,12$ & $61,90 \pm 11,12$ \\
Median & 55,73 & 33,39 & 78,92 & 62,74 \\
Min/Max & $39,46 / 89,06$ & $21,25 / 46,50$ & $55,65 / 106,25$ & $37,44 / 83,98$ \\
P value & $\mathbf{0 . 0 0 0}$ & $\mathbf{0 . 0 0 0}$ & $\mathbf{0 . 0 0 0}$ & $\mathbf{0 . 0 0 0}$ \\
\hline
\end{tabular}

Min-max, minimum-maximum; SD, standard deviation.

\section{DISCUSSION}

Vas deferens ligation (=Vasectomy), is a safe procedure in male contraception and use widely in the world (5). The experimental data is rather controversial and there is no general agreement about the effect of vasectomy on testicular and vas deferens histology.

In order to investigate the effects and damage of vasectomy, degenerative changes in the testicular tissue have also been observed following vasectomy in several species including human $(19,20)$, guinea pig (21), rabbit (22), dog (23) and monkey (24).
Moreover, the histological structure of testicular tissue was damaged after vasectomy and increased in proportion to time (25). However; after vasectomy operation, some recovery at different times was also shown at humans (at 2 years) (19) and rats (at 1 to 3 months) (26)

In our study, we examined that the effects of unilateral vas deferens ligation on histological alterations in the structure of the testis and vas deferens and VEGF immuno-expression changes in the testis of the prepubertal and pubertal rat. 
We found that ductus deferens ligation caused some histological changes in the testis, decreased seminiferous tubule size, and that the development of the spermatogenic cell line was affected at an advanced stage in present study.

Process of the vasectomy suddenly prevents the flow of sperm and seminal fluid, resulting in a sudden increase in pressure in the seminiferous tubules. Such degeneration takes places through pressure damaging the seminiferous epithelium (27). These changes may vary depending on the area where the obstruction is located $(28,29)$. Vas deferens ligation also has negative effects on spermatogenesis, which is the process that including germ cell proliferation and differentiation. Spermatogenic degeneration after vas deferens ligation has been reported in many studies $(6,7,19,22,30)$.

Flickinger et al. previously described the vasectomy was not having a negative effect on the testes and rat testis remained a normal structure after vasectomy in pubertal and pre-pubertal period $(31,32)$. However, as a result of some studies, it has been determined that the spermatogenesis process has deteriorated after vasectomy and the histological structure of the testis has been damaged. Neaves et al. stated that reduction in tubule diameter, depletion of advanced germinal cells and fusion of spermatids in vasectomized rats after 3 months' surgery (33).

In the light of this information, the studies have focused especially on vas deferens obstruction (27, 31-37). In this study, testicular degeneration was associated with decreasing the diameter of the seminiferous tubule and thickness epithelium at both pre-pubertal and pubertal period. Then, it was noticed that the primary spermatocytes, secondary spermatocytes and spermatids series following the spermatogonia on the basal membrane could not be distinguished in a regular and clear form in the vas deferens ligation group. Our study agreed with previous literature as much as the diameter of seminiferous tubules were altered and decreased. In addition, we observed that testicular atrophy in vas deferens ligation group. Degeneration at prepubertal groups was much more than pubertal groups. The testes continue to produce sperm after vasectomy but, does not leave the body. As a result of pressure in epididymis, sperm granulomas are observed in the epididymis and vas deferens. McDonald et al, sperm granuloma develops following vasectomy (8). At other studies, sperm granulomas may be composed at the vasectomy site in some rats in 1 week-3 months after vasectomy surgery operation $(3,4$, 38). Conversely, in our study sperm granulomas were not seen in testes and vas deferens. Grupta et al have been investigated that effects of vasectomy in men and observed after 1month vasectomy comprehensive degeneration of the germinal epithelium and some intertubular fibrosis (19). In this study, it was also determined that degeneration of intersitisium and loss of connective tissue cells in vasectomized pubertal and pre-pubertal rats.

Mc. Vicar et al showed that the least affected cells from the vasectomy were Sertoli cells, whereas the most affected were spermatogenic cells (11, 15). Furthermore, Aydos at all reported that one month after vasectomy, vacuoles and loss of spermatogenic cells were seen in the seminiferous tubules, but the Leydig cells did not show any changes (3). At other experiment, Sarrat et al have noticed influence of vasectomy on rats and dogs after four months following ligation operation. They observed that changes in the thickening of the basement membrane, atrophic the seminiferous tubules, hypertrophy of the interlobular interstitial tissue, while they did not see an increase in the number of Leydig cells (23). Similar to these researches, there were no any changes at Sertoli cell and Leydig cell in our study.

Vascular endothelial growth factor (VEGF) is a major regulator of physiological and pathological angiogenesis (12-14). Nalbandian et al. investigated that VEGF is expressed in Sertoli cells, and VEGFR-2 and VEGFR-1 receptors are expressed in spermatogonial stem cells and advanced germ cell types, respectively. The authors have concluded that VEGF may play a potential regulatory role in the spermatogenesis process with VEGFR-1 and VEGFR-2 (39). In another study demonstrated that VEGF has been implicated in both angiogenesis and seminiferous cord formation (40).

In our histochemical findings, VEGF immunoreactivity was observed for the spermatogenic cells in the seminiferous tubules and in the endothelial cells of the blood vessels in the pre-pubertal and pubertal control group. In contrast, we found that VEGF immunopositivity were not detected in the spermatogenic series and endothelium of blood vessel in vasectomized preand pubertal all rats. VEGF immunostaining was observed strongly for spermatogenic series and Sertoli cells in compared to vas deferens ligation pubertal group while VEGF immunoreactivity was not observed for the sections of testis in the ligation group of pubertal rat. Many studies have previously emphasized, there is a significant reduction in the number of spermatogenic cells and interstitial fibrosis developed among seminiferous tubules after vasectomy or vas deferens ligation. Therefore, it is possible to explain the absence of VEGF immunoreactivity because of the damage of the cells on the testes in vasectomy group according to the control group.
In summary, it is possible to propose VEGF as an intratesticular regulatory factor being crucial for the maintenance of normal physiological function of the testis.

In conclusion, we showed that the bilateral vasectomy operation may have effects on male infertility due to changes in testes and ductus deferens at prepubertal and pubertal period. However, it was considered necessary to support it with another methods and clinical investigations.

\section{Conflict of interest}

No conflict of interest was declared by the authors.

\section{REFERENCES}

1. Patel A, Smith R. Vasectomy reversal: a clinical update. Asian Journal of Andrology 2016; 18: 365-71.

2. Pile JM, Barone MA. Demographics of Vasectomy-USA and International. Urologic Clinics of North America 2009; 36: 295-305.

3. Aydos K, Kupeli B, Soygur T, Unsal A, Erden E, Tulunay O, et al. Analysis of the relationship between histologic alterations and the generation of reactive oxygen species in vasectomized rat testes. Urology 1998; 51: 510-5.

4. Singh SK, Chakravarty S. Histologic changes in the mouse testis after bilateral vasectomy. Asian journal of andrology 2000; 2: 115-20.

5. Weiske WH. Vasectomy. Andrologia 2001; 33: 125-34.

6. Whyte J, Sarrat R, Cisneros A, Whyte A, Mazo R, Torres A, et al. The vasectomized testis. International surgery 1999; 85: 167-74.

7. Kubota Y, Sasaki S, Kubota H, Tatsura H, Kohri K. A study on the mechanism of the spermatogenic damage after vasectomy in rats. Nihon Hinyokika Gakkai zasshi The japanese journal of urology 2001; 92: 13-22.

8. McDonald SW. Vasectomy review: sequelae in the human epididymis and ductus deferens. Clinical Anatomy 1996; 9: 337-42.

9. McGinn J, Sim I, Bennett N, McDonald S. Observations on multiple sperm granulomas in the rat epididymis following vasectomy. Clinical Anatomy 2000; 13: $185-94$.

10. Tait C, McGinn J, Milne E, Bennett N, McDonald S. Macrophages of the sperm granuloma 3 months after vasectomy in the Albino Swiss rat. Clinical Anatomy 2000; 13: 267-76

11. McVicar C, O'neill D, McClure N, Clements B, McCullough S, Lewis S. Effects of vasectomy on spermatogenesis and fertility outcome after testicular sperm extraction combined with ICSI. Human Reproduction 2005; 20: 2795-800.

12. Ferrara N, Gerber H-P, LeCouter J. The biology of VEGF and its receptors. Nature medicine 2003; 9: 669-76.

13. Leung DW, Cachianes G, Kuang W-J, Goeddel DV, Ferrara N. Vascular endothelial growth factor is a secreted angiogenic mitogen. Science 1989; 246: 1306.

14. Senger DR, Galli SJ, Dvorak AM, Perruzzi CA, Harvey VS, Dvorak HF. Tumor cells secrete a vascular permeability factor that promotes accumulation of ascites fluid. Science 1983; 219: 983-5.

15. Rudolfsson SH, Wikström $P$, Jonsson A, Collin O, Bergh A. Hormonal regulation and functional role of vascular endothelial growth factor $A$ in the rat testis. Biology of reproduction 2004; 70: 340-7.

16. Brown LF, Yeo K-T, Berse B, Morgentaler A, Dvorak HF, Rosen S. Vascular permeability factor (vascular endothelial growth factor) is strongly expressed in the normal male genital tract and is present in substantial quantities in semen. The Journal of urology 1995; 154: 576-9.

17. Ergün S, Kilic N, Fiedler W, Mukhopadhyay A. Vascular endothelial growth factor and its receptors in normal human testicular tissue. Molecular and cellular endocrinology 1997; 131: 9-20.

18. Korpelainen EI, Karkkainen MJ, Tenhunen A, Lakso M, Rauvala H, Vierula $M$, et al. Overexpression of VEGF in testis and epididymis causes infertility in transgenic mice: evidence for nonendothelial targets for VEGF. The Journal of cell biology 1998; 143: 1705-12.

19. Gupta A, Kothari L, Dhruva A, Bapna R. Surgical sterilization by vasectomy and its effect on the structure and function of the testis in man. British Journal of Surgery 1975; 62: 59-63.

20. Jarow JP, Budin RE, Dym M, Zirkin BR, Noren S, Marshall FF. Quantitative pathologic changes in the human testis after vasectomy: a controlled study. New England Journal of Medicine 1985; 313: 1252-6.

21. Aitken H, Kumarakuru S, Orr R, Reid O, Bennett N, McDonald S. Effect of long-term vasectomy on seminiferous tubules in the guinea pig. Clinical Anatomy 1999; 12: 250-63.

22. Kong LS, Huang AP, Deng XZ, Yang ZW. Quantitative (stereological) study of the effects of vasectomy on spermatogenesis in rabbits. Journal of anatomy 2004; 205: 147-56.

23. Sarrat R, Whyte J, Torres A, Lostale F, Díaz MP. Experimental vasectomy and testicular structure. Histology and histopathology 1996; 11: 1-6. 
24. Lohiya N, Tiwary S, Ansari A, Watts N. Long-term vasectomy effects on testis and accessory sex organ function in Langur monkey. Acta europaea fertilitatis 1986; 18: 207-11.

25. Shen $K$, Yang $Y$, Tang $X$, Huang $M$, Li H, Shen $H$, et al. Effect of vasectomy on apoptosis in spermatogenic cells of the male rat. Hua xi yi ke da xue xue bao= Journal of West China University of Medical Sciences= Huaxi yike daxue xuebao 1998; 29: 402-6.

26. Longquan R, Qiang W, Kishimoto $M$, Watanabe G, Jaroenporn S, Kazuyoshi $\mathrm{T}$. Effect of short period vasectomy on $\mathrm{FSH}, \mathrm{LH}$, inhibin and testosterone secretions, and sperm motility in adult male rats. Experimental animals 2011; 60: 47-56.

27. Contuk G, Orun O, Demiralp-Ekşioğlu E, Ercan F. Morphological alterations and distribution of occludin in rat testes after bilateral vasectomy. Acta histochemica 2012; 114: 244-51.

28. Flickinger CJ. The effects of vasectomy on the testis. Mass Medical Soc 1985.

29. Flickinger CJ, Baran ML, Howards SS, Herr JC. Degeneration of the seminiferous epithelium following epididymal obstruction in prepubertal rats. The Anatomical Record 1999; 254: 76-86.

30. Shiraishi K, Takihara H, Naito K. Quantitative analysis of testicular interstitial fibrosis after vasectomy in humans. Aktuelle Urologie 2003; 34 : 262-4.

31. Flickinger CJ. Ultrastructure of the rat testis after vasectomy. The Anatomical Record 1972; 174: 477-93.
32. Charles J, Herr JC, Baran ML, Howards SS. Testicular Development and Formation of Spermatic Granulomas of Epididymis After Obstruction of Vas Deferens in Immature Rats. The Journal of urology 1995; 154: 1539-44.

33. Neaves W. The effect of vasectomy on the testes of inbred Lewis rats. Journal of reproduction and fertility 1978; 54: 405-11.

34. Paufler S, Foote R. Spermatogenesis in the rabbit following ligation of the epididymidis at different levels. The Anatomical Record 1969; 164: 339-47.

35. Collins $P$, Tsang $W$. An assessment of the function of the seminiferous tubules and interstitium of the rat testis following ligation of the vasa efferentia. Biology of reproduction 1979; 20: 671-80.

36. Flickinger $\mathrm{CJ}$, Herr JC, Howards SS, Sisak JR, Gleavy JM, Fusia TJ, et al. Early testicular changes after vasectomy and vasovasostomy in Lewis rats. The Anatomical Record 1990; 227: 37-46.

37. Soler C, Blazquez C, Pertusa J, Nunez M, Nunez J, Nunez A. A comparison of the effects of bilateral efferent duct ligation and of partial epididymectomy on the testes of rats. Reproduction, Fertility and Development 1990; 2: 321-6. 38. Ma L, Guo Y, Yuan Y, Li Y-G, Deng X-Z, Yang Z-W. Morphometric study of the testis and reproductive tract (including sperm granuloma) after vasectomy in mature rats. Asian Journal of Andrology 2016; 18: 66-73.

39. Nalbandian A, Dettin L, Dym M, Ravindranath N. Expression of vascular endothelial growth factor receptors during male germ cell differentiation in the mouse. Biology of Reproduction 2003; 69: 985-94.

40. Baltes-Breitwisch MM, Artac RA, Bott RC, McFee RM, Kerl JG, Clopton DT, et al. Neutralization of vascular endothelial growth factor antiangiogenic isoforms or administration of proangiogenic isoforms stimulates vascular development in the rat testis. Reproduction 2010; 140: 319-29. 